\title{
Pengaruh Komposisi Media Tanam dan Lama Perendaman dalam Larutan Urine Sapi terhadap Pertumbuhan Setek Lada (Piper nigrum Linn)
}

\author{
Influence of Composition of Planting Media and Old Immersion in Cow Urine Solution to \\ Pepper Spinning Growth (Piper nigrum Linn) \\ Zulfikar Zulmah ${ }^{1}$, Nurhayati $^{1}$, Erita Hayati $^{2}{ }^{2}$ \\ ${ }^{1}$ Program Studi Agroteknologi, Fakultas Pertanian, Universitas Syiah Kuala
}

\begin{abstract}
Abstrak. Penelitian ini bertujuan untuk mengetahui pengaruh komposisi media tanam dengan lama perendaman dalam larutan urine sapi terhadap pertumbuhan setek lada serta interaksi kedua faktor tersebut. Penelitian ini telah dilaksanakan di University Farm Fakultas Pertanian Universitas Syiah Kuala. Pada bulan Februari sampai April 2016. Rancangan percobaan yang digunakan pada penelitian ini adalah Rancangan Acak Kelompok (RAK) pola faktorial 4x4 dengan 3 ulangan, sehingga terdapat 16 kombinasi perlakuan dan 48 unit percobaan setiap satuan diwakili oleh 2 tanaman sehingga keseluruhan terdapat 96 tanaman. Adapun faktor yang diteliti yaitu komposisi media tanam dengan 4 taraf yaitu $\mathbf{M}_{0}(\operatorname{tanah}), \mathbf{M}_{1}(\operatorname{tanah}+\operatorname{sekam}+$ pupuk kandang = 1:1:2), $\mathbf{M}_{2}\left(\right.$ tanah + sekam + pupuk kandang = 2:1:1), $\mathrm{M}_{3}$ (tanah + sekam + pupuk kandang = $1: 1: 2)$ dan faktor kedua yaitu lama perendaman dalam larutan urine sapi yaitu $\mathrm{W}_{0}$ (tanpa perendaman), $\mathrm{W}_{1}$ (30 detik), $\mathrm{W}_{2}$ (60 detik), $\mathrm{W}_{3}$ (90 detik). Parameter yang diamati dalam penelitian ini mencakup jumlah tunas , panjang tunas $(\mathrm{cm})$, jumlah daun (helai), berat brangkasan segar $(\mathrm{g})$, berat akar kering $(\mathrm{g})$, Berat tunas kering $(\mathrm{g})$, dan volume akar $(\mathrm{ml})$. Hasil penelitian menunjukkan komposisi media tanam dan lama perendaman dalam urine sapi berpengaruh nyata dalam membantu pertumbuhan setek lada.
\end{abstract}

Kata kunci: Media tanam, urine sapi, setek lada.

Abstract. This study aims to determine the effect of planting media composition with long soaking in cow urine solution to the growth of pepper cuttings and the interaction of these two factors. This research has been conducted at University Farm Faculty of Agriculture, Syiah Kuala University. In February to April 2016. The experimental design used in this study was Randomized Block Design (RAK) 4x4 factorial pattern with 3 replications, so there were 16 treatment combinations and 48 experimental units per unit represented by 2 plants so that there were 96 whole plants. The factors studied were the composition of planting medium with 4 levels ie M0 (soil), M1 (soil + husk + manure = 1: 1: 2), M2 (soil + husk + manure = 2: 1: 1), M3 (soil + husk + manure =1: 1: 2) and the second factor is long immersion in cow urine solution W0 (without immersion), W1 (30 seconds), W2 (60 seconds), W3 (90 seconds). Parameters observed in this study included shoot number, shoot length $(\mathrm{cm})$, number of leaves (strands), fresh weight weight $(\mathrm{g})$, dry root weight $(\mathrm{g})$, dry shoot weight $(\mathrm{g})$, and root volume $(\mathrm{ml})$. The results showed that the composition of planting medium and the duration of immersion in cow urine significantly influenced the growth of pepper cuttings.

Keywords: Planting media, cow urine, cuttings of pepper.

\section{PENDAHULUAN}

Tanaman lada merupakan salah satu jenis tanaman batangan berbentuk akar-akaran. Tanaman penghasil rempah-rempah yang bernama latin Piper nigrum Linn. Ini masuk ke indonesia sejak abad XVI (sekitar tahun 1547). Lada sudah dikenal masyarakat luas. Buktinya, buah lada setiap hari dimanfaatkan sebagai bumbu masakan. Mengingat banyaknya pemanfaatan buah lada hitam dan lada putih maka pemasarannya pun mudah, (sarpian, 2004).

Lada termasuk tanaman yang banyak mengandung manfaat pada buahnya. Lada putih berguna untuk bumbu masak sebagai penyedap dan pelezat, pengawet daging, campuran bahan obat-obatan tradisional dan juga dapat dijadikan minuman kesehatan. Sedangkan lada hitam digunakan minyaknya yang wangi sebagai parfum (Rosyadi, 2010). 
Salah satu faktor rendahnya produktivitas tanaman lada yaitu pengadaan bibit yang kurang maksimal. Sebaiknya diadakan pengadaan bibit tanaman lada secara vegetatif. (Rukmana, 2003). Perbanyakan tanaman secara setek lebih efektif dan efisien dalam budidaya tanaman lada. Perbanyakan lada dengan setek lebih menguntungkan karena menghasilkan populasi tanaman yang homogen dan memiliki sifat yang sama dengan induknya. (Balai Informasi Pertanian Irian Jaya, 1994).

Tanaman lada tumbuh baik apabila media tanam yang digunakan sesuai dengan syarat yang dibutuhkan. Setek lada menyukai media tanam yang gembur dan mudah menyerap air. Media tanam lada biasanya digunakan berupa pupuk kandang, arang sekam dan tanah, yang berfungsi menyediakan unsur hara yang dibutuhkan oleh tanaman sehingga dapat tumbuh dan berkembang dengan baik (Dalimoenthe, 1996).

Selain media tanam, penggunaan zat pengatur tumbuh juga mempengaruhi pertumbuhan setek lada. Secara umum zat pengatur tumbuh dibagi menjadi lima kelompok yaitu auksin, giberellin, sitokinin, asam absistat (ABA) dan etilen. Dari lima macam hormon tersebut yang berperan penting dalam pembentukan dan pertumbuhan akar terdapat pada auksin. Golongan hormon auksin terdiri dari Indole Acetic Acid (IAA) dan Naphthalene Acetic Acid (NAA). Kedua zat pengatur tumbuh ini merupakan hormon auksin sintetik yang mempunyai aktifitas yang sama dengan hormon auksin alami (Kusumo, 2004).

Urine sapi adalah limbah yang berbentuk cairan atau berada dalam fase cair (air seni atau urine) dapat merangsang pertumbuhan akar karena mengandung auksin. Auksin merupakan salah satu zat pengatur tumbuh (ZPT) yang berperan penting pada proses pertumbuhan dan perkembangan suatu tanaman. (Budianto et al., 2013).

\section{METODE PENELITIAN}

Penelitian ini telah dilaksanakan di University Farm Fakultas Pertanian Universitas Syiah Kuala. Waktu pelaksanaan telah dimulai dari bulan Februari sampai April 2016.

\section{MATERI DAN METODE}

Tanaman lada yang akan digunakan yaitu varietas Natar 1 sebanyak 144 setek dengan panjang $40 \mathrm{~cm}$ terdiri dari 4 ruas. Zat pengatur tumbuh yang digunakan cairan urine sapi sebanyak $500 \mathrm{ml}$. Media tanam yang digunakan yaitu tanah seberat $85 \mathrm{~kg}$, arang sekam seberat $4 \mathrm{~kg}$, pupuk kandang seberat $20 \mathrm{~kg}$, polibag ukuran $25 \times 30 \mathrm{~cm}$ sebanyak 144 polibag, sarung tangan dan aquades sebanyak $4500 \mathrm{ml}$, gelas ukur, paranet $65 \%$, ayakan pasir, timbangan digital, ember, gembor, meteran, stopwatch serta plastik.

\section{Metode Penelitian}

\section{Analisis Statistik}

Rancangan percobaan yang akan digunakan pada penelitian ini adalah Rancangan Acak Kelompok (RAK) pola faktorial 4x4 dengan 3 ulangan, sehingga terdapat 16 kombinasi perlakuan dan 48 unit percobaan. Setiap satuan diwakili oleh 2 tanaman

Pengaruh Komposisi Media Tanam dan Lama Perendaman dalam Larutan Urine Sapi terhadap Pertumbuhan Setek Lada (Piper nigrum Linn) (Zulfikar Zulmah, Nurhayati, Erita Hayati ) 
sehingga keseluruhan terdapat 96 tanaman. Ada 2 faktor yang diteliti yaitu pengaruh komposisi media tanam dan lama perendaman urine sapi..

\section{Pelaksanaan Penelitian}

\section{Pembuatan rumah kasa}

Sebelum menentukan tempat pembibitan setek lada, sebaiknya lihat disekitar tempat untuk pendirian rumah kasa bagus atau kurang memadai. Lalu bersihkan dan ukur lahan yang hendak di pakai berkisar 4x5 m, kemudian membuat atap rumah kasa model lengkung. Lalu pemasangan atap yang beralas plastik dan dinding yang di balut mengunakan paranet $65 \%$. Selanjutnya letakan polibag di dalamnya sesuai label perlakuan.

\section{Persiapan media tanam}

Media tanam yang digunakan pada penelitian ini yaitu tanah jenis aluvial yang berasal dari desa indrapuri berlokasi pinggiran sungai Kabupaten Aceh Besar. Tanah dikering anginkan selama 2 minggu lalu diayak hingga halus, dengan arang sekam yang telah dibakar, dan pupuk kandang yang telah matang. Kemudian ketiga jenis media tersebut di campur hingga merata, selanjutnya isi kedalam polibag sesuai dengan perbandingan yang telah di tentukan berdasarkan label perlakuan.

\section{Persiapan setek}

Dalam penelitian ini setek yang digunakan bervarietas Natar 1. Setek yang di ambil dari batang induknya, kriteria pohon induk setek lada ini yaitu berumur \pm 1 tahun dan terbebas dari hama dan penyakit. Setiap batang setek terdiri dari 4 ruas atau buku-buku. Setek yang dibutuhkan dalam penelitian ini berjumlah 144 batang dan keseluruhan setek ini di ambil pada bagian sulur panjat setek lada.

\section{Perlakuan perendaman urine sapi}

Sebelum ditanam, setek terlebih dahulu di pisahkan menurut perlakuan perendaman, lalu campurkan urine sapi dan aquades dalam satu wadah dengan menggunakan konsentrasi $10 \%$ aduk hingga merata dengan urine sapi sebanak $500 \mathrm{ml}$ dan aquades $4500 \mathrm{ml}$, masukkan setek yang telah dipisahkan kedalam wadah dan rendam setek sesuai perlakuan.

\section{Penanaman}

Penanam setek lada di lakukan pada sore hari hingga selesai yang bertujuan agar tidak terjadi penguapan air secara berlebihan sehingga bibit akan kekurangan air dan kelamaan akan mati. setek ditanam sedalam $10 \mathrm{~cm}$ dengan posisi miring 450, kemudian polibag diatur sesuai perlakuan.

\section{Pemeliharaan}

Pemeliharaan yang dilakukan meliputi penyiraman dengan intensitas penyiraman tiap polybag setek lada. Pencabutan gulma ataupun yang dianggap mengganggu pertumbuhan setek lada.

Pengaruh Komposisi Media Tanam dan Lama Perendaman dalam Larutan Urine Sapi terhadap Pertumbuhan Setek Lada (Piper nigrum Linn) (Zulfikar Zulmah, Nurhayati, Erita Hayati ) 


\section{Pengamatan}

Adapun parameter yang akan diamati dalam penelitian ini meliputi jumlah tunas , panjang tunas $(\mathrm{cm})$, jumlah daun (helai), berat brangkasan segar $(\mathrm{g})$, berat akar kering $(\mathrm{g})$, Berat tunas kering $(\mathrm{g})$, dan volume akar $(\mathrm{ml})$.

\section{HASIL DAN PEMBAHASAN}

\section{Pengaruh Komposisi Media Tanam terhadap Pertumbuhan Setek Lada}

\section{Pengaruh Komposisi Media Tanam Terhadap Jumlah Tunas}

Hasil uji $F$ menunjukkan bahwa komposisi media tanam setek lada berpengaruh sangat nyata terhadap jumlah tunas umur 56 dan 70 HST. Setelah umur 28 HST berpengaruh nyata dan umur 42 HST tidak berpengaruh nyata. Rata-rata pertumbuhan jumlah tunas setek lada dapat disajikan pada Tabel 1.

Tabel 1. Rata-rata Pertumbuhan Jumlah Tunas Setek Lada pada Komposisi Media Tanam.

\begin{tabular}{ccccc}
\hline \multirow{2}{*}{$\begin{array}{c}\text { Komposisi Media Tanam } \\
\text { Tanah+Sekam+P.Kandang }\end{array}$} & \multicolumn{4}{c}{ Jumlah Tunas } \\
\cline { 2 - 5 } & 28 HST & 42 HST & 56 HST & 70 HST \\
\hline Tanah $\left(\mathrm{M}_{0}\right)$ & $2,500 \mathrm{a}$ & 2,500 & $2,500 \mathrm{a}$ & $2,583 \mathrm{a}$ \\
$1: 1: 2\left(\mathrm{M}_{1}\right)$ & $2,792 \mathrm{ab}$ & 2,792 & $2,833 \mathrm{~b}$ & $2,875 \mathrm{~b}$ \\
$2: 1: 1\left(\mathrm{M}_{2}\right)$ & $2,500 \mathrm{a}$ & 2,583 & $2,625 \mathrm{a}$ & $2,750 \mathrm{a}$ \\
$1: 1: 1\left(\mathrm{M}_{3}\right)$ & $2,917 \mathrm{~b}$ & 2,917 & $3,083 \mathrm{~b}$ & $3,167 \mathrm{c}$ \\
BNT & 0,330 & - & 0,265 & 0,278 \\
\hline
\end{tabular}

Keterangan : Angka yang diikuti oleh huruf yang sama dalam kolom yang sama tidak berbeda nyata pada taraf $5 \%(0,05)$.

Tabel 1 menunjukkan bahwa pertumbuhan jumlah tunas setek lada umur 28 dan 56 HST nilai lebih banyak di jumpai pada komposisi media tanam 1:1:1 $\left(\mathrm{M}_{3}\right)$, akan tetapi tidak berbeda nyata dengan komposisi media tanam 1:1:2 $\left(\mathrm{M}_{1}\right)$. Tapi berbeda nyata dengan komposisi media tanam 2:1:1 $\left(\mathrm{M}_{2}\right)$ dan Tanah $\left(\mathrm{M}_{0}\right)$. Pada jumlah tunas setek lada umur 70 HST lebih banyak di jumpai pada komposisi media tanam 1:1:1 $\left(\mathrm{M}_{3}\right)$ yang berbeda nyata dengan komposisi media tanam tanam 2:1:1 $\left(\mathrm{M}_{2}\right)$, 1:1:2 $\left(\mathrm{M}_{1}\right)$ dan tanah $\left(\mathrm{M}_{0}\right)$.

\section{Pengaruh komposisi media tanam terhadap panjang tunas}

Hasil uji $\mathrm{F}$ menunjukkan bahwa komposisi media tanam setek lada berpengaruh sangat nyata terhadap panjang tunas umur 42, 56 dan 70 HST. Setelah umur 28 HST berpengaruh nyata dan umur 42 HST tidak berpengaruh nyata. Rata-rata pertumbuhan panjang tunas setek lada dapat disajikan pada Tabel 2.

Tabel 2. Rata-rata Pertumbuhan Panjang Tunas (cm) Setek Lada pada Komposisi Media Tanam.

\begin{tabular}{ccccc}
\hline \multirow{2}{*}{$\begin{array}{c}\text { Komposisi Media Tanam } \\
\text { Tanah+Sekam+P.Kandang }\end{array}$} & \multicolumn{4}{c}{ Panjang Tunas (cm) } \\
\cline { 2 - 5 } & $28 \mathrm{HST}$ & $42 \mathrm{HST}$ & $56 \mathrm{HST}$ & 70 HST \\
\hline Tanah $\left(\mathrm{M}_{0}\right)$ & $3,292 \mathrm{a}$ & $3,750 \mathrm{a}$ & $4,417 \mathrm{a}$ & $5,042 \mathrm{a}$ \\
$1: 1: 2\left(\mathrm{M}_{1}\right)$ & $3,917 \mathrm{a}$ & $4,208 \mathrm{a}$ & $6,500 \mathrm{~b}$ & $6,833 \mathrm{~b}$ \\
$2: 1: 1\left(\mathrm{M}_{2}\right)$ & $4,583 \mathrm{~b}$ & $5,208 \mathrm{~b}$ & $7,167 \mathrm{~b}$ & $8,167 \mathrm{c}$ \\
$1: 1: 1\left(\mathrm{M}_{3}\right)$ & $4,917 \mathrm{~b}$ & $6,083 \mathrm{~b}$ & $6,792 \mathrm{~b}$ & $7,917 \mathrm{bc}$ \\
\hline \hline
\end{tabular}

Pengaruh Komposisi Media Tanam dan Lama Perendaman dalam Larutan Urine Sapi terhadap Pertumbuhan Setek Lada (Piper nigrum Linn) (Zulfikar Zulmah, Nurhayati, Erita Hayati ) 


\section{BNT}

1,116

1,116

0,865

1,225

Keterangan : Angka yang diikuti oleh huruf yang sama dalam kolom yang sama tidak berbeda nyata pada taraf $5 \%(0,05)$.

Tabel 2 menunjukkan bahwa pertumbuhan panjang tunas setek lada umur 28 dan 42 HST nilai lebih tinggi dijumpai pada komposisi media 1:1:1 $\left(\mathrm{M}_{3}\right)$, akan tetapi tidak berbeda nyata dengan komposisi media tanam 2:1:1 $\left(\mathrm{M}_{2}\right)$. Tapi berbeda nyata dengan komposisi media tanam 1:1:2 $\left(\mathrm{M}_{1}\right)$ dan Tanah $\left(\mathrm{M}_{0}\right)$. Pada tinggi setek lada umur 56 HST lebih tinggi dijumpai pada komposisi media 2:1:1 $\left(\mathrm{M}_{2}\right)$, akan tetapi tidak berbeda nyata dengan komposisi media tanam tanah + sekam + pupuk kandang 1:1:1 $\left(\mathrm{M}_{3}\right)$ dan 1:1:2 $\left(\mathrm{M}_{1}\right)$. Tapi berbeda nyata dengan komposisi media $\left(\mathrm{M}_{0}\right)$. Pada tinggi setek lada umur 70 HST lebih tinggi dijumpai pada komposisi media tanam 2:1:1 $\left(\mathrm{M}_{2}\right)$, akan tetapi tidak berbeda nyata dengan komposisi media tanam tanah 1:1:1 $\left(\mathrm{M}_{3}\right)$. Tapi berbeda nyata dengan komposisi media 1:1:2( $\left.\mathrm{M}_{1}\right)$ dan tanah $\left(\mathrm{M}_{0}\right)$.

\section{Pengaruh komposisi media tanam terhadap jumlah daun}

Hasil uji $\mathrm{F}$ menunjukkan bahwa komposisi media tanam setek lada berpengaruh sangat nyata terhadap jumlah daun umur 56 dan 70 HST. setelah umur 28 dan 42 HST berpengaruh nyata. Rata-rata pertumbuhan jumlah daun setek lada dapat disajikan pada Tabel 3.

Tabel 3. Rata-rata Pertumbuhan Jumlah Daun (helai) Setek Lada pada Komposisi Media Tanam.

\begin{tabular}{cllll}
\hline Komposisi Media Tanam & \multicolumn{4}{c}{ Jumlah Daun (helai) } \\
\cline { 2 - 5 } Tanah+Sekam+P.Kandang & 28 HST & 42 HST & $56 \mathrm{HST}$ & $70 \mathrm{HST}$ \\
\hline Tanah $\left(\mathrm{M}_{0}\right)$ & $1,167 \mathrm{a}$ & $1,333 \mathrm{a}$ & $1,333 \mathrm{a}$ & $1,333 \mathrm{a}$ \\
$1: 1: 2\left(\mathrm{M}_{1}\right)$ & $1,083 \mathrm{a}$ & $1,333 \mathrm{a}$ & $1,333 \mathrm{a}$ & $1,333 \mathrm{a}$ \\
$2: 1: 1\left(\mathrm{M}_{2}\right)$ & $1,333 \mathrm{ab}$ & $1,583 \mathrm{ab}$ & $1,750 \mathrm{ab}$ & $1,833 \mathrm{~b}$ \\
$1: 1: 1\left(\mathrm{M}_{3}\right)$ & $1,583 \mathrm{~b}$ & $2,000 \mathrm{~b}$ & $2,083 \mathrm{~b}$ & $2,250 \mathrm{~b}$ \\
BNT & 0,368 & 0,435 & 0,402 & 0,378
\end{tabular}

Keterangan : Angka yang diikuti oleh huruf yang sama dalam kolom yang sama tidak berbeda nyata pada taraf $5 \%(0,05)$.

Tabel 3 menunjukkan bahwa pertumbuhan jumlah daun setek lada umur 28, 42, 56 dan 70 HST nilai lebih banyak dijumpai pada komposisi media 1:1:1 $\left(\mathrm{M}_{3}\right)$, akan tetapi tidak berbeda nyata dengan komposisi media tanam 2:1:1 $\left(\mathrm{M}_{2}\right)$. Tapi berbeda nyata dengan komposisi media tanam 1:1:2 $\left(\mathrm{M}_{1}\right)$ dan Tanah $\left(\mathrm{M}_{0}\right)$.

Pengaruh Komposisi Media Tanam dan Lama Perendaman dalam Larutan Urine Sapi terhadap Pertumbuhan Setek Lada (Piper nigrum Linn) (Zulfikar Zulmah, Nurhayati, Erita Hayati ) 


\section{Pengaruh komposisi media tanam terhadap berat berangkasan segar, berat akar kering, Berat Tunas kering dan volume akar}

Hasil uji $\mathrm{F}$ menunjukkan bahwa komposisi media tanam setek lada berpengaruh sangat nyata terhadap berat berangkasan segar, selanjutnya berat akar kering dan volume akar berpengaruh nyata dan berpengaruh tidak nyata terhadap berat tunas kering. Rata-rata pertumbuhan setek lada umur 70 HST, dapat disajikan pada Tabel 4.

Tabel 4. Rata-rata Berat Berangkasan Segar Setek, Berat Tunas Kering, Berat Akar Kering, dan Volume Akar Setek Lada pada Komposisi Media Tanam.

\begin{tabular}{lccccc}
\hline \multirow{2}{*}{$\begin{array}{c}\text { Parameter yang } \\
\text { Diamati }\end{array}$} & \multicolumn{5}{c}{ Komposisi Media Tanam } \\
& Tanah+Sekam+P.Kandang & \multirow{2}{*}{ BNT } \\
\cline { 2 - 5 } & Tanah & $1: 1: 2$ & $2: 1: 1$ & $1: 1: 1$ & \\
\hline berat berangkasan segar $(\mathrm{g})$ & $3,239 \mathrm{a}$ & $4,583 \mathrm{~b}$ & $4,747 \mathrm{~b}$ & $5,653 \mathrm{~b}$ & 1,151 \\
berat akar kering (g) & 0,380 & 0,307 & 0,383 & 0,313 & - \\
Berat Tunas kering (g) & $0,381 \mathrm{a}$ & $0,483 \mathrm{ab}$ & $0,350 \mathrm{a}$ & $0,594 \mathrm{~b}$ & 0,182 \\
Volume akar $(\mathrm{g})$ & $2,667 \mathrm{a}$ & $3,417 \mathrm{ab}$ & $3,333 \mathrm{a}$ & $4,458 \mathrm{~b}$ & 1,232
\end{tabular}

Keterangan: Angka yang diikuti oleh huruf yang sama dalam kolom yang sama tidak berbeda nyata pada taraf $5 \%(0,05)$.

Tabel 4 menunjukkan bahwa berat brangkasan segar lebih berat dijumpai pada komposisi media tanam 1:1:1 $\left(\mathrm{M}_{3}\right)$ akan tetapi tidak berbeda nyata dengan komposisi media tanam 2:1:1 $\left(\mathrm{M}_{2}\right)$ dan 1:1:2 $\left(\mathrm{M}_{1}\right)$, tapi berbeda nyata dengan komposisi media tanam tanah $\left(\mathrm{M}_{0}\right)$. Pada berat tunas kering dan volume akar lebih berat dijumpai pada komposisi media tanam 1:1:1 $\left(\mathrm{M}_{3}\right)$ akan tetapi tidak berbeda nyata dengan komposisi media tanam 1:1:2 $\left(\mathrm{M}_{1}\right)$, tapi berbeda nyata dengan komposisi media tanam 2:1:1 $\left(\mathrm{M}_{2}\right)$ dan tanah $\left(\mathrm{M}_{0}\right)$.

\section{Pengaruh Lama Perendaman dalam urine sapi terhadap Pertumbuhan Tanaman setek Lada}

\section{Pengaruh lama perendaman dalam urine sapi terhadap pertumbuhan jumlah tunas}

Hasil uji F menunjukkan bahwa lama perendaman dalam urine sapi setek lada berpengaruh sangat nyata terhadap panjang tunas umur 56 dan 70 HST. Akan tetapi umur 28 dan 42 HST berpengaruh nyata. Rata-rata pertumbuhan jumlah tunas setek lada dapat disajikan pada Tabel 5.

Tabel 5. Rata-rata Pertumbuhan Jumlah Tunas Setek Lada pada Lama Perendaman dalam Urine Sapi.

\begin{tabular}{ccccc}
\hline \multirow{2}{*}{ Lama Perendaman dalam Urine Sapi } & \multicolumn{4}{c}{ Jumlah tunas } \\
\cline { 2 - 5 } & 28 HST & 42 HST & 56 HST & 70 HST \\
\hline Tanpa Perendaman $\left(\mathrm{W}_{0}\right)$ & $2,625 \mathrm{a}$ & $2,625 \mathrm{a}$ & $2,708 \mathrm{a}$ & $2,708 \mathrm{a}$ \\
30 detik $\left(\mathrm{W}_{1}\right)$ & $2,458 \mathrm{a}$ & $2,458 \mathrm{a}$ & $2,500 \mathrm{a}$ & $2,625 \mathrm{a}$ \\
60 detik $\left(\mathrm{W}_{2}\right)$ & $2,917 \mathrm{~b}$ & $2,917 \mathrm{~b}$ & $2,958 \mathrm{~b}$ & $3,042 \mathrm{~b}$ \\
90 detik $\left(\mathrm{W}_{3}\right)$ & $2,708 \mathrm{ab}$ & $2,792 \mathrm{~b}$ & $2,875 \mathrm{~b}$ & $3,000 \mathrm{~b}$ \\
BNT & 0,330 & 0,323 & 0,265 & 0,278 \\
\hline
\end{tabular}

Keterangan : Angka yang diikuti oleh huruf yang sama dalam kolom yang sama tidak berbeda nyata pada taraf $5 \%(0,05)$.

Tabel 5 menunjukkan bahwa pertumbuhan jumlah tunas setek lada umur 28, 42, 56 dan 70 HST nilai lebih banyak dijumpai pada lama perendaman 60 detik (W2) akan tetapi tidak berbeda nyata dengan lama perendaman 90 detik (W3) tapi berbeda nyata dengan lama perendaman 30 detik (W1) dan tanpa perendaman (W0). 


\section{Pengaruh lama perendaman dalam urine sapi terhadap pertumbuhan panjang tunas}

Hasil uji F menunjukkan bahwa lama perendaman dalam urine sapi setek lada berpengaruh sangat nyata terhadap panjang tunas umur 56 HST. Namun umur 28, 42 dan 70 HST tidak berpengaruh nyata. Rata-rata pertumbuhan panjang tunas setek lada dapat disajikan pada Tabel 6.

Tabel 6. Rata-rata Pertumbuhan Panjang Tunas (cm) Setek Lada pada Lama Perendaman dalam Urine Sapi.

\begin{tabular}{ccccc}
\hline \multirow{2}{*}{ Lama Perendaman dalam Urine Sapi } & \multicolumn{4}{c}{ Panjang tunas $(\mathrm{cm})$} \\
\cline { 2 - 5 } & 28 HST & 42 HST & 56 HST & 70 HST \\
\hline Tanpa Perendaman $\left(\mathrm{W}_{0}\right)$ & 3,833 & 4,292 & $5,667 \mathrm{a}$ & 6,250 \\
30 detik $\left(\mathrm{W}_{1}\right)$ & 4,542 & 5,000 & $6,250 \mathrm{ab}$ & 6,750 \\
60 detik $\left(\mathrm{W}_{2}\right)$ & 4,292 & 4,875 & $5,708 \mathrm{a}$ & 7,583 \\
90 detik $\left(\mathrm{W}_{3}\right)$ & 4,042 & 5,083 & $7,250 \mathrm{~b}$ & 7,375 \\
BNT & - & - & 0,865 & -
\end{tabular}

Keterangan : Angka yang diikuti oleh huruf yang sama dalam kolom yang sama tidak berbeda nyata pada taraf $5 \%(0,05)$.

Tabel 6 menunjukkan bahwa pertumbuhan panjang tunas setek lada umur 56 HST nilai lebih tinggi dijumpai pada lama perendaman 90 detik (W3) akan tetapi tidak berbeda nyata dengan lama perendaman 30 detik (W1) tapi berbeda nyata dengan lama perendaman 60 detik (W2) dan tanpa perendaman (W0).

\section{Pengaruh lama perendaman dalam urine sapi terhadap pertumbuhan jumlah daun}

Hasil uji F menunjukkan bahwa lama perendaman dalam urine sapi setek lada berpengaruh sangat nyata terhadap jumlah daun umur 70 HST. Selanjutnya umur 42 dan 56 HST berpengaruh nyata dan umur 28 HST tidak berpengaruh nyata. Rata-rata pertumbuhan jumlah daun setek lada dapat disajikan pada Tabel 7.

Tabel 7. Rata-rata Pertumbuhan Jumlah Daun (helai) Setek Lada pada Lama Lerendaman dalam Urine Sapi.

\begin{tabular}{ccccc}
\hline \multirow{2}{*}{ Lama Perendaman dalam Urine Sapi } & \multicolumn{4}{c}{ Jumlah daun (helai) } \\
\cline { 2 - 5 } & $28 \mathrm{HST}$ & $42 \mathrm{HST}$ & $56 \mathrm{HST}$ & $70 \mathrm{HST}$ \\
\hline Tanpa Perendaman $\left(\mathrm{W}_{0}\right)$ & 1,167 & $1,250 \mathrm{a}$ & $1,250 \mathrm{a}$ & $1,333 \mathrm{a}$ \\
30 detik $\left(\mathrm{W}_{1}\right)$ & 1,083 & $1,417 \mathrm{a}$ & $1,583 \mathrm{a}$ & $1,583 \mathrm{a}$ \\
60 detik $\left(\mathrm{W}_{2}\right)$ & 1,417 & $1,750 \mathrm{~b}$ & $1,750 \mathrm{~b}$ & $1,833 \mathrm{~b}$ \\
90 detik $\left(\mathrm{W}_{3}\right)$ & 1,500 & $1,833 \mathrm{~b}$ & $1,917 \mathrm{~b}$ & $2,000 \mathrm{~b}$ \\
BNT & - & 0,435 & 0,402 & 0,378 \\
\hline
\end{tabular}

Keterangan : Angka yang diikuti oleh huruf yang sama dalam kolom yang sama tidak berbeda nyata pada taraf $5 \%(0,05)$.

Tabel 7 menunjukkan bahwa pertumbuhan jumlah daun setek lada umur 42, 56 dan 70 HST nilai lebih banyak dijumpai pada lama perendaman 90 detik (W3) akan tetapi tidak berbeda nyata dengan lama perendaman 60 detik (W2) tapi berbeda nyata dengan lama perendaman 30 detik (W1) dan tanpa perendaman (W0).

Pengaruh lama perendaman dalam urine sapi terhadap berat berangkasan segar, berat akar kering, Berat Tunas kering dan volume akar

Pengaruh Komposisi Media Tanam dan Lama Perendaman dalam Larutan Urine Sapi terhadap Pertumbuhan Setek Lada (Piper nigrum Linn) (Zulfikar Zulmah, Nurhayati, Erita Hayati ) 
Hasil uji $\mathrm{F}$ menunjukkan bahwa lama perendaman dalam urine sapi setek lada berpengaruh sangat nyata terhadap volume akar, selanjutnya berat akar kering berpengaruh nyata dan berpengaruh tidak nyata terhadap berat brangkasan segar dan berat tunas kering. Rata-rata pertumbuhan setek lada umur 70 HST, dapat disajikan pada Tabel 8.

Tabel 8. Rata-rata Berat Berangkasan Segar Setek, Berat Tunas Kering, Berat Akar Kering, dan Volume Akar Setek Lada pada Lama Perendaman dalam Urine Sapi

\begin{tabular}{lccccc}
\multirow{2}{*}{$\begin{array}{c}\text { Parameter yang } \\
\text { Diamati }\end{array}$} & \multicolumn{3}{c}{ Lama Perendaman dalam Urine Sapi } & BNT \\
\cline { 2 - 4 } & $\begin{array}{c}\text { Tanpa } \\
\text { Perendaman } \\
\left(\mathrm{W}_{0}\right)\end{array}$ & $\begin{array}{c}30 \text { detik } \\
\left(\mathrm{W}_{1}\right)\end{array}$ & $\begin{array}{c}60 \text { detik } \\
\left(\mathrm{W}_{2}\right)\end{array}$ & $\begin{array}{c}90 \text { detik } \\
\left(\mathrm{W}_{3}\right)\end{array}$ \\
\hline berat berangkasan segar $(\mathrm{g})$ & 3,081 & 4,472 & 5,047 & 4,923 & - \\
berat akar kering $(\mathrm{g})$ & $0,289 \mathrm{a}$ & $0,223 \mathrm{a}$ & $0,402 \mathrm{~b}$ & $0,469 \mathrm{~b}$ & 0,163 \\
Berat Tunas kering $(\mathrm{g})$ & 0,434 & 0,401 & 0,375 & 0,598 & - \\
Volume akar $(\mathrm{g})$ & $2,750 \mathrm{a}$ & $2,542 \mathrm{a}$ & $4,208 \mathrm{~b}$ & $4,375 \mathrm{~b}$ & 1,232 \\
\hline
\end{tabular}

Keterangan : Angka yang diikuti oleh huruf yang sama dalam kolom yang sama tidak berbeda nyata pada taraf $5 \%(0.05)$

Tabel 8 menunjukkan bahwa berat akar kering dan volume akar setek lada nilai lebih berat dijumpai pada lama perendaman 90 detik (W3) akan tetapi tidak berbeda nyata dengan lama perendaman 60 detik (W2) tapi berbeda nyata dengan lama perendaman 30 detik (W1) dan tanpa perendaman (W0).

\section{Interaksi antara Komposisi Media Tanam dengan Lama Perendaman dalam Larutan Urine Sapi terhadap Pertumbuhan Tanaman Setek Lada}

Hasil uji $\mathrm{F}$ menunjukan bahwa terdapat interaksi sangat nyata antara komposisi media tanam dan lama perendaman dalam larutan urine sapi terhadap panjang tunas setek lada umur 56 HST, volume akar umur 70 HST dan berinteraksi nyata pada jumlah daun setek lada umur 70 HST.

\section{Panjang tunas umur 56 HST}

Rata-rata panjang tunas setek lada umur 56 HST akibat interaksi antara media tanam dan lama perendaman dalam larutan urine sapi yang telah di uji dengan BNT $(0,05)$, dapat dilihat pada tabel 9.

Tabel 9. Rata-rata Panjang Tunas akibat Interaksi Komposisi Media Tanam dengan Lama Perendaman dalam urine sapi Umur 56 HST.

\begin{tabular}{ccccc}
\hline \multirow{2}{*}{$\begin{array}{c}\text { Komposisi Media Tanam } \\
\text { Tanah + Sekam + P. Kandang }\end{array}$} & $\begin{array}{c}\text { Tanpa } \\
\text { Perendaman } \\
\left(\mathrm{W}_{0}\right)\end{array}$ & $\begin{array}{c}30 \text { detik } \\
\left(\mathrm{W}_{1}\right)\end{array}$ & $\begin{array}{c}60 \text { detik } \\
\left(\mathrm{W}_{2}\right)\end{array}$ & $\begin{array}{c}90 \text { detik } \\
\left(\mathrm{W}_{3}\right)\end{array}$ \\
\hline Tanah $\left(\mathrm{M}_{0}\right)$ & $3,667 \mathrm{Aa}$ & $4,333 \mathrm{Aba}$ & $5,667 \mathrm{Ba}$ & $4,000 \mathrm{Aa}$ \\
$1: 1: 2\left(\mathrm{M}_{1}\right)$ & $7,333 \mathrm{Bb}$ & $5,667 \mathrm{Aa}$ & $6,000 \mathrm{Aa}$ & $7,000 \mathrm{Abb}$ \\
$2: 1: 1\left(\mathrm{M}_{2}\right)$ & $6,000 \mathrm{Ab}$ & $7,667 \mathrm{Abb}$ & $6,000 \mathrm{Aa}$ & $9,000 \mathrm{Bc}$ \\
$1: 1: 1\left(\mathrm{M}_{3}\right)$ & $5,667 \mathrm{Ab}$ & $7,333 \mathrm{Bb}$ & $5,167 \mathrm{Aa}$ & $9,000 \mathrm{Bc}$ \\
BNT & & \multicolumn{2}{c}{1,730} & \\
\hline
\end{tabular}

Keterangan : Angka yang diikuti oleh huruf yang sama berbeda tidak nyata pada taraf 0,05 (Uji BNT). Huruf kapital merupakan notasi pada baris, huruf kecil merupakan notasi pada kolom.

Tabel 9 memperlihatkan bahwa terdapat perbedaan panjang tunas umur 56 HST akibat komposisi media tanam yang berbeda pada lama perendaman yang berbeda. Panjang tunas per

Pengaruh Komposisi Media Tanam dan Lama Perendaman dalam Larutan Urine Sapi terhadap Pertumbuhan Setek Lada (Piper nigrum Linn) (Zulfikar Zulmah, Nurhayati, Erita Hayati ) 
tanaman nilai terbaik $(9,000)$ pada setek lada, diperoleh dari komposisi media tanam tanah + sekam + pupuk kandang dengan perbandingan 1:1:1 (M3) dari perlakuan lama perendaman 90 detik (W3). Tetapi tidak berbeda dengan komposisi media tanam tanah + sekam + pupuk kandang dengan perbandingan 2:1:1 (M2), meskipun komposisi ini menjadi lebih baik pada perlakuan lama perendaman 90 detik (W3). Panjang tunas setek lada nilai terendah di jumpai pada komposisi media tanam tanah (M0) dengan perlakuan tanpa perendaman (W0). Kondisi di atas menunjukkan bahwa lama perendaman hanya cocok diaplikasikan pada komposisi media tanam tanah + sekam + pupuk kandang dengan perbandingan 1:1:1 (M3).

\section{Volume akar}

Rata-rata volume akar setek lada umur 70 HST akibat interaksi antara komposisi media tanam dan lama perendaman dalam larutan urine sapi yang telah di uji dengan BNT (0.05). dapat dilihat pada tabel 10 .

Tabel 10. Rata-rata Volume Akar akibat Interaksi Komposisi Media Tanam dengan Lama Perendaman dalam Urine Sapi Umur 70 HST.

\begin{tabular}{ccccc}
\hline $\begin{array}{c}\text { Komposisi Media Tanam } \\
\text { Tanah + Sekam }+\end{array}$ & \multicolumn{4}{c}{ Lama Perendaman dalam Urine Sapi } \\
\cline { 2 - 5 } P. Kandang & $\begin{array}{c}\text { Tanpa Perendaman } \\
\left(\mathrm{W}_{0}\right)\end{array}$ & $\begin{array}{c}30 \text { detik } \\
\left(\mathrm{W}_{1}\right)\end{array}$ & $\begin{array}{c}60 \text { detik } \\
\left(\mathrm{W}_{2}\right)\end{array}$ & $\begin{array}{c}90 \text { detik } \\
\left(\mathrm{W}_{3}\right)\end{array}$ \\
\hline Tanah $\left(\mathrm{M}_{0}\right)$ & $1,333 \mathrm{Aa}$ & $3,000 \mathrm{ABab}$ & $2,500 \mathrm{Aa}$ & $3,833 \mathrm{Ba}$ \\
$1: 1: 2\left(\mathrm{M}_{1}\right)$ & $3,167 \mathrm{ABa}$ & $1,000 \mathrm{Aa}$ & $2,833 \mathrm{Aa}$ & $6,667 \mathrm{Bb}$ \\
$2: 1: 1\left(\mathrm{M}_{2}\right)$ & $2,833 \mathrm{ABa}$ & $1,500 \mathrm{Aa}$ & $6,500 \mathrm{Bb}$ & $2,500 \mathrm{Aa}$ \\
$1: 1: 1\left(\mathrm{M}_{3}\right)$ & $3,667 \mathrm{Aa}$ & $4,667 \mathrm{Ab}$ & $5,000 \mathrm{Ab}$ & $4,500 \mathrm{Aab}$ \\
BNT & & 2,463 & & \\
\hline
\end{tabular}

Keterangan : Angka yang diikuti oleh huruf yang sama berbeda tidak nyata pada taraf 0,05 (Uji BNT). Huruf kapital merupakan notasi pada baris, huruf kecil merupakan notasi pada kolom

Tabel 10 memperlihatkan bahwa terdapat perbedaan volume akar umur 70 HST akibat komposisi media tanam yang berbeda pada lama perendaman yang berbeda. Volume akar per tanaman nilai terbaik $(6,667)$ pada setek lada, diperoleh dari komposisi media tanam tanah + sekam + pupuk kandang dengan perbandingan 1:1:2 (M1) dari perlakuan lama perendaman 90 detik (W3). Tetapi tidak berbeda dengan komposisi media tanam tanah + sekam + pupuk kandang dengan perbandingan 2:1:1 (M2), meskipun komposisi ini menjadi lebih baik pada perlakuan lama perendaman 60 detik (W2).

Volume akar setek lada nilai terendah di jumpai pada komposisi media tanam tanah (M0) dengan perlakuan tanpa perendaman (W0). Kondisi di atas menunjukkan bahwa lama perendaman hanya cocok diaplikasikan pada komposisi media tanam tanah + sekam $+p$. kandang dengan perbandingan 1:1:2 (M1).

\section{Jumlah daun 70 HST}

Rata-rata jumlah daun setek lada umur 70 HST akibat interaksi antara komposisi media tanam dan lama perendaman dalam larutan urine sapi yang telah di uji dengan BNJ (0.05), dapat dilihat pada tabel 11 .

Tabel 11. Rata-rata Jumlah Daun akibat Interaksi Komposisi Media Tanam dengan Lama Perendaman dalam Urine Sapi Umur 70 HST.

\begin{tabular}{ccccc}
\hline \multirow{2}{*}{ Komposisi Media Tanam } & \multicolumn{3}{c}{ Lama Perendaman dalam Urine Sapi } \\
\cline { 2 - 4 } & Tanpa Perendaman & 30 detik & 60 detik & 90 detik \\
\hline \hline
\end{tabular}

Pengaruh Komposisi Media Tanam dan Lama Perendaman dalam Larutan Urine Sapi terhadap Pertumbuhan Setek Lada (Piper nigrum Linn) (Zulfikar Zulmah, Nurhayati, Erita Hayati ) 


\begin{tabular}{ccccc}
\hline Tanah + Sekam + P. Kandang & $\left(\mathrm{W}_{0}\right)$ & $\left(\mathrm{W}_{1}\right)$ & $\left(\mathrm{W}_{2}\right)$ & $\left(\mathrm{W}_{3}\right)$ \\
\hline Tanah $\left(\mathrm{M}_{0}\right)$ & $2,000 \mathrm{Aa}$ & $1,333 \mathrm{Aa}$ & $1,333 \mathrm{Aa}$ & $1,667 \mathrm{Aa}$ \\
$1: 1: 2\left(\mathrm{M}_{1}\right)$ & $1,667 \mathrm{Aba}$ & $1,333 \mathrm{Aa}$ & $2,000 \mathrm{Bab}$ & $1,000 \mathrm{Aa}$ \\
$2: 1: 1\left(\mathrm{M}_{2}\right)$ & $2,000 \mathrm{Aa}$ & $2,000 \mathrm{Aa}$ & $1,667 \mathrm{Aa}$ & $2,000 \mathrm{Aab}$ \\
$1: 1: 1\left(\mathrm{M}_{3}\right)$ & $1,667 \mathrm{Aa}$ & $1,667 \mathrm{Aa}$ & $2,333 \mathrm{ABb}$ & $3,333 \mathrm{Bb}$ \\
BNT & \multicolumn{4}{c}{0,756} \\
\hline
\end{tabular}

Keterangan :Angka yang diikuti oleh huruf yang sama berbeda tidak nyata pada taraf 0,05 (Uji BNJ). Huruf kapital merupakan notasi pada baris, huruf kecil merupakan notasi pada kolom

Tabel 11 memperlihatkan bahwa terdapat perbedaan jumlah daun umur 70 HST akibat komposisi media tanam yang berbeda pada lama perendaman yang berbeda. Jumlah daun per tanaman nilai terbaik $(3,333)$ pada setek lada, diperoleh dari komposisi media tanam tanah + sekam + pupuk kandang dengan perbandingan 1:1:1 (M3) dari perlakuan lama perendaman 90 detik (W3). Tetapi tidak berbeda dengan perlakuan lama perendaman 60 detik (W2), meskipun perendaman ini menjadi lebih baik pada komposisi media tanam tanah + sekam + pupuk kandang dengan perbandingan 1:1:1 (M3).

Jumlah daun setek lada nilai terendah di jumpai pada komposisi media tanam tanah (M0) dengan perlakuan lama perendaman 30 detik (W1). Kondisi di atas menunjukkan bahwa lama perendaman hanya cocok diaplikasikan pada komposisi media tanam tanah + sekam + pupuk kandang dengan perbandingan 1:1:1 (M3).

\section{Pembahasan}

\section{Pengaruh komposisi media tanam terhadap pertumbuhan setek lada.}

Hasil penelitian menunjukkan bahwa komposisi media tanam berpengaruh terhadap pertumbuhan setek lada. Dari keseluruhan komposisi media tanam yang dicobakan hasil lebih baik dijumpai pada komposisi media tanam 1:1:1 Tanah + Sekam + P. Kandang, hal ini di duga karena Media tanam pada perlakuan 1:1:1 Tanah + Sekam + Pupuk Kandang dapat mendorong proses pertumbuhan akar serta pertumbuhan tunas lebih maksimal.

Pada Media tanam pada perlakuan 1:1:2 dan 2:1:1 Tanah + Sekam + P. Kandang pertumbuhan setek lada tidak maksimal yang disebabkan kepadatan media tanam yang menyebabkan pertumbuhan akar terhambat serta kebutuhan air pada setek tidak terpenuhi dan mengalami kegagalan dan kematian pada setek lada.

Mulyana, (2010) menyatakan bahwa komposisi media tumbuh yang biasa digunakan petani untuk pembibitan bisa terdiri atas campuran pasir, tanah, sekam (1:1:1) tanah, kompos (3:1) tanah, pasir, pupuk, kandang (1:1:1) tanah, bokasi, pasir (3:1:1) atau tanah dan sekam $(1: 1)$.

Penggunaan media Tanah + Sekam + P. Kandang lebih menguntungkan dikarenakan selain lebih ringan dan hemat juga memiliki dampak positif bagi lingkungan serta dapat memanfaatkan limbah pertanian. Media berbahan organik juga bagus dalam memperbaiki bahan bagi penyangga tanam seperti sekam dapat membaiki drainase media tanam itu sendiri.

Menurut Hartman and Kester, (1959) bahwa pemberian media tanam meningkatkan persentase setek berakar, mempercepat jumlah pemunculan tunas, serta meningkatkan munculnya akar, tunas, dan daun secara bersamaan sehingga pertumbuhan tanaman akan lebih baik. Media tanam yang baik adalah media tumbuh tanam yang porositas yang besar sehingga akar dapat memperoleh udara dan air yang cukup, serta mampu menyediakan unsur-unsur hara yang diperlukan oleh tanaman. Untuk pembibitan tanaman perkebunan, komposisi media tanam yang biasa digunakan adalah tanah, kompos, dan arang sekam (Sumarna, 2002).

Pengaruh Komposisi Media Tanam dan Lama Perendaman dalam Larutan Urine Sapi terhadap Pertumbuhan Setek Lada (Piper nigrum Linn) (Zulfikar Zulmah, Nurhayati, Erita Hayati ) 


\section{Pengaruh lama perendaman dalam urine sapi terhadap pertumbuhan setek lada}

Hasil penelitian menunjukkan bahwa lama perendaman dalam larutan urine sapi berpengaruh terhadap pertumbuhan setek lada. Dari keseluruhan lama perendaman yang di coba hasil lebih baik di jumpai pada lama perendaman 90 detik, hal ini di duga karena auksin yang terdapat dalam urine sapi membantu dalam proses perangsang penyetekan lada dalam laju pertumbuhannya.

Pada perlakuan lainnya lama perendaman dalam urine sapi tanpa perendaman, 30 detik, dan 60 detik. Laju tumbuhan setek lada tergolong lambat pertumbuhan membutuhkan waktu yang lebih lama. Sehingga pertumbuhan bibit setek lada tidak seragam, serta pada beberapa bibit setek lada ada yang tidak tumbuh dan mati.

Pujiharti, (1998) menyatakan bahwa, urine sapi dapat digunakan sebagai sumber auksin. Air kemih ini harus diencerkan dengan air bersih sehingga diperoleh konsentrasi 5 $10 \%$. Pencelupan dilakukan selama 15 - 30 detik menjelang ditanam. Urine ternak sapi memiliki pengaruh yang baik pada perbaikan pertumbuhan terutama pada jumlah daun pada konsentrasi urine $50 \%$ dengan lama perendaman 1 jam.

Urine sapi adalah limbah yang berbentuk cairan atau berada dalam fase cair (air seni atau urine) dapat merangsang pertumbuhan akar karena mengandung auksin. Auksin merupakan salah satu zat pengatur tumbuh (ZPT) yang berperan penting pada proses pertumbuhan dan perkembangan suatu tanaman, Budianto et al,. (2013).

Auksin juga menjadi salah satu pacuan hormon tumbuh yang tak lepas dari proses pertumbuhan dan perkembangan tanaman. Salah satu peran auksin adalah menstimulasi terjadinya perpanjangan sel pada pucuk (Artanti, 2007). Gardner et al,. (1991) menambahkan bahwa auksin menpunyai pengaruh nyata dalam pertumbuhan pucuk.

\section{Interaksi antara Komposisi Media Tanam dengan Lama Perendaman dalam Larutan}

\section{Urine Sapi terhadap Pertumbuhan Setek Lada.}

Hasil penelitian menunjukkan bahwa terdapat interaksi antara komposisi media tanam dengan lama perendaman, lebih baik dijumpai pada kombinasi media tanam 1:1:1 Tanah + Sekam + Pupuk Kandang dengan waktu perendaman 90 detik, hal ini disebabkan adanya respon pertumbuhan tanaman setek lada akibat perlakuan urine sapi dan juga ketergantungan pada penggunaan komposisi media tanam begitu pula sebaliknya.

Menurut Erliandi et al,. 2015 kombinasi perlakuan komposisi media tanam dan lama perendaman auksin pada M1T3 memberikan hasil rataan tertinggi yaitu 1,40 helai. Hal ini disebabkan karena adanya interaksi yang baik antara media tanam dengan auksin pada awal muncul tunas. Dimana, bibit menyerap air dan unsur hara dari bahan organik (termasuk kompos blotong) yang terkandung dalam media tanam, begitu pula dengan auksin yang terkandung dalam atonik mempengaruhi proses metabolisme dan memacu pertumbuhan pada bibit yang terdapat di dalam media tanam, sehingga keduanya saling mempengaruhi dalam pertumbuhan bibit tersebut.

Jenis media tanam, konsentrasi auksin dan kombinasi keduanya berpengaruh nyata terhadap pertumbuhan tunas. Hal ini juga diterangkan Gardner et al,. (1991) yang menyatakan jumlah buku dan ruas yang sama dengan jumlah daun, ketiganya mempunyai asal ujung yang sama di dalam fitomer. Bahan setek yang di gunakan dalam penelitian ini memiliki buku dan ruas yang sama.

Meskipun demikian ada perbedaan pengaruh jenis media dan konsentrasi auksin terhadap jumlah daun dan panjang tunas karena menurut Gardner et al,. (1991) jumlah daun

Pengaruh Komposisi Media Tanam dan Lama Perendaman dalam Larutan Urine Sapi terhadap Pertumbuhan Setek Lada (Piper nigrum Linn) (Zulfikar Zulmah, Nurhayati, Erita Hayati ) 
dan panjang tunas juga di pengaruhi faktor genetika dan lingkungan serta adanya kemampuan dari setek bibit tersebut dalam menunjang pertumbuhannya. faktor luar adalah media perakaran, kelembaban, suhu, cahaya dan faktor lingkungan sangat mempengaruhi pertumbuhan tanaman Suprapto, (2004).

\section{KESIMPULAN DAN SARAN}

Kombinasi antara komposisi media tanam tanah + sekam + p. kandang dengan perbandingan 1:1:1 dengan lama perendaman dalam urine sapi 90 detik. Memberikan pertumbuhan setek lada terbaik. Dan Perlu dilakukan penelitian lebih lanjut mengenai pengaruh komposisi media tanam dan lama perendaman dalam larutan urine sapi dengan meningkatkan jenis media tanam dan waktu perendaman terhadap pertumbuhan, hasil dan kualitas setek lada

\section{DAFTAR PUSTAKA}

Artanti, F.Y. 2007. Pengaruh Macam Pupuk Organik Cair dan Konsentrasi IAA terhadap Pertumbuhan Setek Tanaman Stevia (Stevia rebaudiana Bertoni M.). Skripsi S1 FP UNS Surakarta

Budianto. E. A., K. Badami, A.Arsyadmunir. 2013. Pengaruh kombinasi macam ZPT dengan lama perendaman yang berbeda terhadap keberhasilan pembibitan sirih merah (Piper crocatum ruiz \& pav) secara setek. Agrovigor 6(2): 103-11.1

Dalimoenthe.S.L.1996. Sekam Sebagai Media Pembibitan Stek Teh. Warta Teh dan Kina Rubrik Ilmiah Kol 7 (4): 115-112. Pusat Penelitian teh dan kina Gambung.

Erliandi, Ratna Rosanty Lahay, Toga Simanungkalit. 2015 Pengaruh Komposisi Media Tanam dan Lama Perendaman Auksin pada Bibit Tebu Teknik Bud Chip. urnal Online Agroekoteknologi . ISSN No. 2337- 6597 Vol.3, No.1 : 378 - 389 Desember 2015.

Gardner, F.P.R.B. Pierce dan R.L. Mitchell. 1991. Fisiologi Tanaman Budidaya. Terj. Universitas Indonesia Press. Jakarta.

Hartmann HT dan DE Kester. 1959. Plant Propagation Principles And Practices. Second Edition. Prentice-Hall Inc., New Jersey.

Kusumo, S. 2004. Zat Pengatur Tumbuh Tanaman. Yasaguna : Jakarta.

Lembar Informasi Pertanian (LIPTAN) BIP Irian Jaya Diterbitkan oleh: Balai Informasi Pertanian Irian Jaya Jl. Yahim-Sentani, Jayapura No. September 1994. No.144/94.

Mulyono, D. 2010. Pengaruh Zat Pengatur Tumbuh Auksin: Indole Butiric Acid (Iba) Dan Sitokinin: Benzil Amino Purine (Bap) Dan Kinetin Dalam Elongasi Pertunasan Gaharu (Aquilaria beccariana). Pusat Teknologi Produksi Pertanian-BPPT.

Kusumo, S. 2004. Zat Pengatur Tumbuh Tanaman. Yasaguna : Jakarta.

Pujiharti, Y. 1998. Respon Pertumbuhan Setek Tanaman Lada (Piper nigrum L.) yang Berasal dari Berbagai Ketinggian pada Tanaman Induk TerhadapBerbagai Media Tanam. J. Agrotropika. 13 (2) : 29-33.

Rosyadi, M. A. 2010. Klasifikasi dan Morfologi Tanaman Lada .(http://www.matematikacerdas.wordpress.com/2010/01/25/klasifikasi-danmorfologi-tanaman-lada). Diakses Pada Tanggal 15 Desember 2016.

Rukmana, R, H. 2003. Usaha Tani Lada Perdu. Kanisius. Yogyakarta.

Sarpian, T. 2004. Lada: Mempercepat Berbuah, Meningkatkan Produksi, Memperpanjang Umur. Penebar Swadaya. Jakarta

Pengaruh Komposisi Media Tanam dan Lama Perendaman dalam Larutan Urine Sapi terhadap Pertumbuhan Setek Lada (Piper nigrum Linn) (Zulfikar Zulmah, Nurhayati, Erita Hayati ) 
Sumarna, Y. 2002. Budidaya Jati, Jakarta: Penebar swadaya.

Suprapto, A. 2004. Auksin: Zat pengatur tumbuh penting meningkatkan mutu setek tanaman. J. Penelitian 21(1): 81-90. 